\title{
Antioxidant and antimicrobial properties of five medicinal Libyan plants extracts
}

\author{
Rabia Alghazeer ${ }^{1^{\star}}$, Hussein El-Saltani ${ }^{1}$, Nabeel Saleh ${ }^{1}$, Asma Al-Najjar $^{2}$, Fatma Hebail $^{1}$ \\ ${ }^{1}$ Chemistry Department, Faculty of Sciences, Tripoli University, Tripoli, Libya; \\ *Corresponding Author: Rabia alghazeer@yahoo.com \\ ${ }^{2}$ Soil Department, Faculty of Agriculture, Tripoli University, Tripoli, Libya
}

Received 10 March 2012; revised 7 April 2012; accepted 19 April 2012

\begin{abstract}
Five Libyan medicinal plants Thapsia garganica, Hammada scoparia, Euphorbia serrata, Hyoscyamus albus and Retama rateam were selected to evaluate their biological activities. Their total phenolic and flavanoid contents were assessed. The antioxidant activity was estimated using 2, 2-diphenyl-1-picrylhydrazyl (DPPH) as free radical scavenger. Their crude extracts showed reducing potential proportional to their concentration. The correlation coefficient $\left(R^{2}\right)$ between antioxidant activity and their total phenolics and flavanoids content is 0.77 and 0.98 respectively. Crude aqueous, methanolic as well as alkaloids extracts of the five plants were tested against a number of G +ve and G -ve sensitive resistant (e.g. MRSA) bacteria beside some fungal species. The aqueous extracts displayed weak antibacterial activity whereas methanolic extracts were profoundly effective against both $G$ +ve and $G$-ve bacteria. The extracts of $E$. serrata and $H$. scoparia were highly effective against $E$. coli in particular. The alkaloid-rich extracts of $H$. albus and $H$. scoparia induced remarkable bacteriostatic and fungistatic effects. The bioactive ingredients of $\boldsymbol{H}$. scoparia, $E$. serrata and $R$. rateam extracts are shown to be potential sources of natural antioxidant and antimicrobial ingredients favoring their possible use in industrial pharmacology on large scale.
\end{abstract}

Keywords: Medicinal Plants; Flavonoids; Free Radical Scavenging Capacity; Antioxidant; Phenolics; Antibacterial; Antifungal

\section{INTRODUCTION}

Medicinal plants MP have been used in folk medicine in Libyan rural areas at relatively cheaper expenses than modern medicine. They have been widely used as diuretics, topical anti-inflammants, and haemostatics [1]. Plants generally produce several secondary metabolites like phe- nols, flavonoids, quinones, tannins, alkaloids, saponins, and sterols which are important sources of biocides and many other pharmaceutical drugs [2-8]. Medicinal plants are important in pharmacological research and drug development [9]. The most important secondary plant metabolites are phenols and flavonoids [10,11], they have distinctive biological activity as natural antioxidants which exceed many other synthetic ones [12].

Antioxidants are used to preserve food quality mainly because they arrest oxidative deterioration of lipids [13, 14]. Moreover, the exploration of naturally occurring antimicrobials for food preservation receives increasing attention due to consumer awareness of natural food products and a growing concern of microbial resistance towards conventional preservatives [15]. These factors have inspired the widespread screening of new plant species for possible medicinal and antioxidant properties, while the isolation and characterization of diverse phytochemicals $[16,17]$.

The relationship between oxidative stress and antioxidants is very often explained in a very simple manner. First, reactive oxygen species (ROS) are reacted together as one functional entity producing destruction compounds such as secondary lipid peroxidation products. However, there are many different ROS that have separate and essential roles in normal physiology and are required for a variety of normal processes. Toxic reactive oxygen (ROS) can be produced by many sources such as ultra violet radiation (UV) and heat from sunlight. These species are substantially reactive and interact with a number of cellular molecules and metabolites thereby leading to a number of destructive processes causing cell damage and neurodegenerative diseases [18]. The aim of this study was to evaluate in vitro antioxidant as well as the antibacterial and antifungal properties of crude methanolic and alkaloid extracts of some Libyan medicinal plants.

\section{MATERIALS AND METHODS}

\subsection{Plant Collection and Materials}

Shade-dried leaves of Euphorbia serrata, Retama rae- 
tem, Thapsia garganica, Hammada scoparia and Hyoscyamus albus that commonly used in folk medicine in Libyan countryside with reference to their utilized parts were subjected to extraction. All plants were collected from different regions of Libya between spring and early summer of 2009, then classified and authenticated by taxonomists, Department of Botany, Faculty of Science, Tripoli University (Tripoli, Libya).

\subsection{Microorganisms}

The bacterial (Bacillus subtilis, Staphylococcus aureus, Escherichia coli, Pseudomonas aeruginosa and Salmonella typhi) and fungal (Rizochtonia solani, Trichoderma spp, Sclerotium spp and Aspergillus niger ) species were kindly provided by the Microbiological Laboratory, Faculty of Pharmacy, Dr. Najat Elghariany Department of Plant protection, Faculty of Agriculture, (Tripoli University) and Mohamed Elghazally Department of Microbiology Biotechnology Research Center (Twaisha), while resistant bacteria (clinically isolated) were kindly provided from the Clinical Microbiology Laboratory, Tripoli Medical Center, (Tripoli, Libya).

\subsection{Preparation of Plant Crude Extracts}

Collected plants were dried at room temperature $\left(25^{\circ} \mathrm{C}\right.$ $\pm 2^{\circ} \mathrm{C}$ ). The dried leaves were powdered with the aid of a clean electric blender and passed through a reasonable mesh sieve, then preserved in an air-tight dark colored glass container. Milled plant material $(20 \mathrm{~g})$ was soaked for 6 hours in $100 \mathrm{ml}$ of distilled water in tightly sealed vessels at room temperature. The same weight of plant materials were extracted with boiling water for $10-15$ min. The methanolic extracts were prepared by extracting the dry leaves powder $(20 \mathrm{~g})$ three times each with $200 \mathrm{ml}$ of methanol. All crude extracts were filtered through Whatman filter paper and kept at $4^{\circ} \mathrm{C}$ until tested.

\subsection{Phytochemical Screening}

Phytochemical screening for major constituent (alkaloids, anthraquinones, coumarins, flavonoids, saponins, tannins, and terpenes) was undertaken using standard qualitative methods that has been described previously [19-23].

\subsection{Alkaloids Extraction}

Powdered plant materials (50 g) were extracted several times with methanol $(300 \mathrm{ml})$. Methanol extraction was continued until the plant material gave a negative result for alkaloids (Mayer's test). The obtained methanolic extract was evaporated under reduced pressure at $40^{\circ} \mathrm{C}$, to minimize any possible thermal degradation of the al- kaloids and other thermolabile compounds. The crude alkaloid mixture was then separated from neutral and acidic materials, and water soluble ingredients. The initial extraction was carried out with aqueous acetic acid. After which, the dichloromethane extraction was carried out and basification. The aqueous solution subjected to further dichloromethane extraction thereafter [24].

\subsection{Determination of Total Polyphenol Content}

The phenolic containing extracts were obtained using a method described by Marinova (2005) [25]. The phenolic contents were determined with the Folin-Ciocalteu method [26]. The tenfold diluted extract was left to react with the Folin-Ciocalteu reagent $(1 \mathrm{ml})$, and then the mixture was neutralized with $\mathrm{Na}_{2} \mathrm{CO}_{3}$. The mixture was thereafter incubated at room temperature for $90 \mathrm{~min}$. Finally, the absorbance was measured using spectrophotometer at $750 \mathrm{~nm}$. The total phenolic content was expressed as mg gallic acid equivalents (GAE)/g sample.

\subsection{Determination of Total Flavonoids Content}

Flavonoid content of the crude extracts was estimated according to the modified method of Marinova (2005) [25]. The diluted standard solutions or plant extract $(0.5$ $\mathrm{ml})$ were separately mixed with $1.5 \mathrm{ml}$ of $80 \%$ ethanol, $0.1 \mathrm{ml}$ of $10 \%$ aluminum chloride (Merck, Germany), $0.1 \mathrm{ml}$ of $1 \mathrm{M}$ potassium acetate (Kemika, Croatia) and $2.8 \mathrm{ml}$ of distilled water. After incubation at room temperature for 30 minutes, the absorbance of the reaction mixture was measured at $415 \mathrm{~nm}$. Rutin (Sigma, Germany) was used for calibration curve $\left(25,50\right.$ and $100 \mu \mathrm{g} \cdot \mathrm{ml}^{-1}$ in $80 \%$ ethanol).

\subsection{Determination of Antioxidant Activity}

\subsubsection{Reducing Power}

The antioxidant activity was investigated using the ferric reducing antioxidant power (FRAP) assay for plant extracts was investigated according to the method of Oyaizu (1986) [27]. Plant extract of 1, 10, 50 or $100 \mathrm{mg}$ in $1 \mathrm{ml}$ of ethanol was mixed with $2.5 \mathrm{ml}$ of phosphate buffer $(2 \mathrm{M}, \mathrm{pH} 6.6)$ and $2.5 \mathrm{ml}$ of potassium ferricyanide $(10 \mathrm{~g} / \mathrm{L})$ then the mixture was incubated at $50^{\circ} \mathrm{C}$ for $20 \mathrm{~min} .1 .5 \mathrm{ml}$ of trichloroacetic acid $(100 \mathrm{~g} / \mathrm{L})$ was added to the mixture, which was then centrifuged at 3000 rpm for $10 \mathrm{~min}$. Finally, $0.5 \mathrm{ml}$ of the supernatant solution was mixed with $1.0 \mathrm{ml}$ of distilled water and $0.5 \mathrm{ml}$ of $\mathrm{FeCI}_{3}(1.0 \mathrm{~g} / \mathrm{L})$ and the absorbance was measured at $665 \mathrm{~nm}$. Increased absorbance of the reaction mixture indicates increasing of reducing power of plant tissue ingredients. 


\subsubsection{DPPH Radical Scavenging Activity}

The free radical scavenging activity quantitatively tested using 2,2-diphenyl-1-picrylhydrazyl (DPPH) based on Wong (2006) method [28]. The initial absorbance of DPPH in methanol was measured at $515 \mathrm{~nm}$ until the absorbance remains constant. A total of $40 \mu \mathrm{l}$ of extract was added to $3 \mathrm{ml}$ of $0.1 \mathrm{mM}$ methalonic DPPH solution. The mixture was incubated at room temperature for 30 min. after that the absorbance at $515 \mathrm{~nm}$ was measured. The percentage of inhibition was calculated using the following formula:

Inhibition $(\%)=$

$\left[\left(\mathrm{A}_{515}\right.\right.$ of control $-\mathrm{A}_{515}$ of sample $) / \mathrm{A}_{515}$ of control $] \times 100$

The $\mathrm{IC}_{50}$ was calculated as the amount of antioxidants present in the sample necessary to reduce the initial DPPH concentration by $50 \%$. All determinations were performed in triplicates.

\subsection{Antibacterial and Antifungal Assessment of Plant Extracts}

The antimicrobial activity of the crude and alkaloid extracts was determined by the "hole-plate diffusion methods" [29]. Each test organism was maintained on nutrient agar slant and was recovered for testing by growth in nutrient broth (Biolab, Difco) for $14 \mathrm{~h}$ at $37^{\circ} \mathrm{C}$ before streaking. Cultures were routinely adjusted to a suspension of $1 \times 10^{6}$ to $2 \times 10^{6} \mathrm{CFU} / \mathrm{ml}$ using pre-made calibration curve representing viable cell count $\left(X \times 10^{6}\right)$ against OD $660 \mathrm{~nm}(Y) .150 \mu \mathrm{l}$ aliquots of the extract were placed into wells of $8 \mathrm{~mm}$ diameter. The plates were kept for $1 \mathrm{~h}$ at $4^{\circ} \mathrm{C}$ for allowing better diffusion of the extract into the agar. Subsequently, plates were incubated at $37^{\circ} \mathrm{C}$ for $18 \mathrm{~h}$. Vancomycin and Tetracycline $(30 \mu \mathrm{g}$ each) were used as positive control while sterile water or $70 \%$ methanol was used as negative control. Diameters of inhibition zones (DIZ) were measured in $\mathrm{mm}$ and the results were recorded as the mean of triplicate experiments.

For fungi, Petri dishes containing $25 \mathrm{ml}$ of Sabaruod dextrose agar (SDA) medium were evenly seeded with $0.5 \mathrm{ml}$ of adjusted fungal inoculum. According to CLSI M38-A2 (for filamentous fungi), $0.5 \mathrm{McF}$ arland standard was used as a reference to visually adjust the turbidity of the fungal suspension [30]. Holes of $8 \mathrm{~mm}$ diameter were punched and filled with $150 \mu \mathrm{l}$ of plant extract, and the plates were incubated at $28^{\circ} \mathrm{C} \pm 1^{\circ} \mathrm{C}$ for 48 hours [31].

\subsection{Determination of Minimum Inhibitory Concentration (MIC)}

Minimum Inhibitory Concentration (MIC) was carried out using agar two fold serial dilution assays [32]. The concentrations $(\mathrm{mg} / \mathrm{ml})$ of extracts were prepared; reference antibiotics and the solvent were also assayed. The MIC was recorded as the lowest concentration of the sample that inhibits visible growth giving clear zones of inhibition after $24 \mathrm{~h}$ incubation.

\subsection{Statistical Analysis}

Data were expressed as means \pm standard deviations (SD) of triplicate determinations and then analyzed by SPSS V.16 (Statistical Program for Social Sciences, SPSS Corporation, Chicago, IL) using one way analysis of variance (ANOVA). $P$ values $<0.05$ were considered to be significant. The Pearsons correlation analysis was performed between antioxidant activity, total phenolic and flavonoids contents.

\section{RESULTS AND DISCUSSION}

\subsection{Phytochemical Screening}

Five Libyan medicinal plants were rottenly screened (as described in methodology) for their phytochemical constituents. Table 1 shows the contents of the phytochemicals obtained from the extraction of the five plants rated from $(+v e)$ for faint to $(++++v e)$ for dense turbidity. Results demonstrated that, most of them are either rich or of moderate content of alkaloids and flavonoids which is the case in most of the families to which these plants belong [33]. Tannins are in almost all investigated plants except $H$. albus. All are of poor levels of saponins except H. albus (Table 1).

\subsection{Total Alkaloids Content}

On the dry weight basis, Figure 1 shows the relatively high percentage of alkaloids content in both $T$. garganica $(1.25 \%)$ and $H$. albus (1\%), while, H. scoparia and $E$. serrata are of moderate content $(0.63 \%, 0.83 \%$ respectively), however, $R$. raetem was comparatively poor $(<0.2 \%)$.

\subsection{Total Phenolics and Flavonoid Content of Tested Medicinal Plants}

Table 2 summarizes the contents of total phenolics, and flavanoid contents of the different plant extracts. Phenolics present in medicinal plants have received considerable attention because of their potential antioxidant activity [34]. Methanol and ethanol were proven as effective solvents to extract antioxidant phenolic compounds [35]. H. scoparia showed the highest total phenolic content (119.76 $\pm 15.76 \mathrm{mg} \mathrm{GAE} / \mathrm{g} \mathrm{DW})$, while $T$. garganica had the lowest value $(28.53 \pm 3.82 \mathrm{mg}$ GAE/g DW). The amount of polyphenolic compounds in E. serrata was significantly higher $(P<0.05)$ compared to their amounts 
Table 1. Preliminary phytochemical screening of extracts of the five tested Libyan medicinal plants.

\begin{tabular}{|c|c|c|c|c|c|}
\hline $\begin{array}{l}\text { Phytochemical } \\
\text { Compounds }\end{array}$ & $\begin{array}{l}\text { Retama raetem } \\
\text { (Fabaceae) }\end{array}$ & $\begin{array}{c}\text { Hammada scoparia } \\
\text { (Chenopodiaceae) }\end{array}$ & $\begin{array}{c}\text { Thapsia garganica } \\
\text { (Apiaceae ) }\end{array}$ & $\begin{array}{c}\text { Euphorbia serrata } \\
\text { (Euphorbiaceae) }\end{array}$ & $\begin{array}{l}\text { Hyoscyamus albus } \\
\text { (Rhamnacea) }\end{array}$ \\
\hline Alkaloids & ++++ ve & +++ ve & +++ ve & $++\mathrm{ve}$ & +++ ve \\
\hline Flavonoids & +++ ve & +++ ve & ++ ve & +++ ve & +++ ve \\
\hline Tannins & $++v e$ & +++ ve & +++ ve & +++ ve & +++ ve \\
\hline Terpenes & $+\mathbf{v e}$ & $++v e$ & +++ ve & ++ ve & $++\mathbf{v e}$ \\
\hline Coumarins & $++\mathbf{v e}$ & $+\mathbf{v e}$ & $+\mathbf{v e}$ & $++\mathbf{v e}$ & -ve \\
\hline Saponins & $+\mathbf{e}$ & +++ ve & +++ ve & + ve & $+\mathbf{v e}$ \\
\hline Anthraquinones & ++ ve & ++ ve & ++ ve & $++v e$ & $++\mathbf{v e}$ \\
\hline
\end{tabular}

$+++\mathrm{ve}$, rich; ++ve, moderate; +ve, poor; -ve, absent.

Table 2. Total polyphenol and flavonoid contents of methanolic extracts of the tested plants.

\begin{tabular}{ccc}
\hline Extract & Polyphenols content $(\mathrm{mg} \mathrm{GAE} / \mathrm{g} \mathrm{DW})$ & Flavonoids content $(\mathrm{mg}$ Rutin/g DW) \\
\hline H. scoparia & $119.76 \pm 15.76$ & $81.07 \pm 6.14$ \\
R. raetem & $89.35 \pm 2.1$ & $45.23 \pm 3.64$ \\
H. albus & $48.54 \pm 7.82$ & $27.39 \pm 0.87$ \\
T. garganica & $28.53 \pm 3.82$ & $13.35 \pm 1.06$ \\
E. serrata & $65.93 \pm 9.45$ & $36.29 \pm 4.76$ \\
\hline
\end{tabular}

DW: dry weight; Results were recorded as (mean $\pm \mathrm{SD}) ;{ }^{*} \mathrm{mg} \mathrm{GAE} / \mathrm{g}$ DW: milligram gallic acid equivalent per gram dry weight; ${ }^{m} \mathrm{mg}$ Rutin/g DW: milligram Rutin equivalent per gram dry weight.

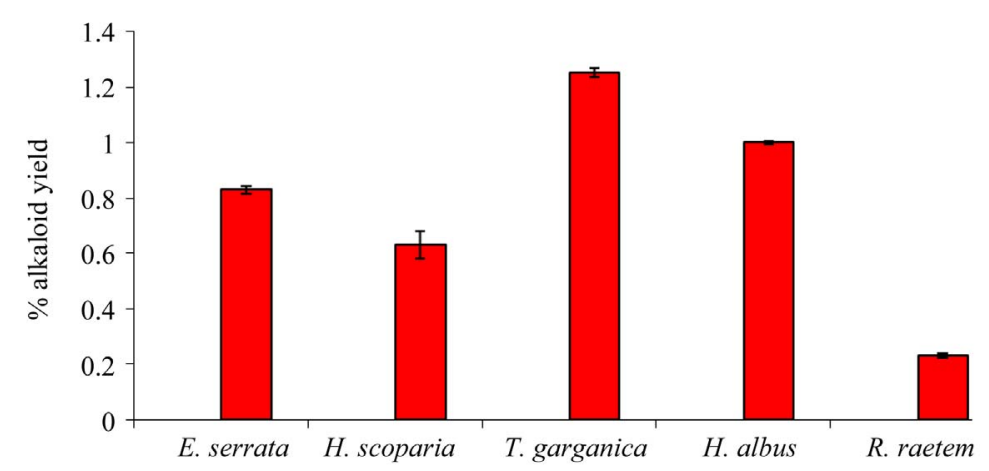

Figure 1. Percentage of alkaloid yield (mg/g plant dry weight) extracted from the five tested medicinal plants.

in H. albus.

Flavonoids is one of the most diverse and widespread groups of natural products which are probably the most important natural phenolics. Several flavonoids have been reported to quench active oxygen species and inhibit in vitro oxidation of low-density lipoproteins [36, 37]. A variety of plant flavonoids and alkaloids have also been shown to be anticarcinogenic in several animal models [38,39]. From analysis, it can be concluded that most of these plants are rich in flavonoids except $T$. garganica (Table 2). The amount of flavonoids in the tested plants varies from 13.35 to $81.07 \mathrm{mg} / \mathrm{g}$ rutin equivalent of the crude extract. The highest flavonoid content was found in $H$. scoparia which was in agreement with pervious study [40], while the lowest amount was obtained in T. garganica [41]. The flavonoid contents obtained from $E$. serrata extract was remarkably higher than its content in $R$. raetem and $H$. albus $(P<0.05)$.

\subsection{Antioxidant Activity}

The antioxidant activity of the investigated botanical methanolic extracts was initially determined using the reducing power and DPPH assays.

\subsubsection{Reducing Power of the Tested Plant Extracts}

Determination of reducing potential can reflect some aspects of antioxidant activity in the extracts (Figure 2). The intensity of color resulting from reduction of ferric ions depends on the reducing potential of the compounds 


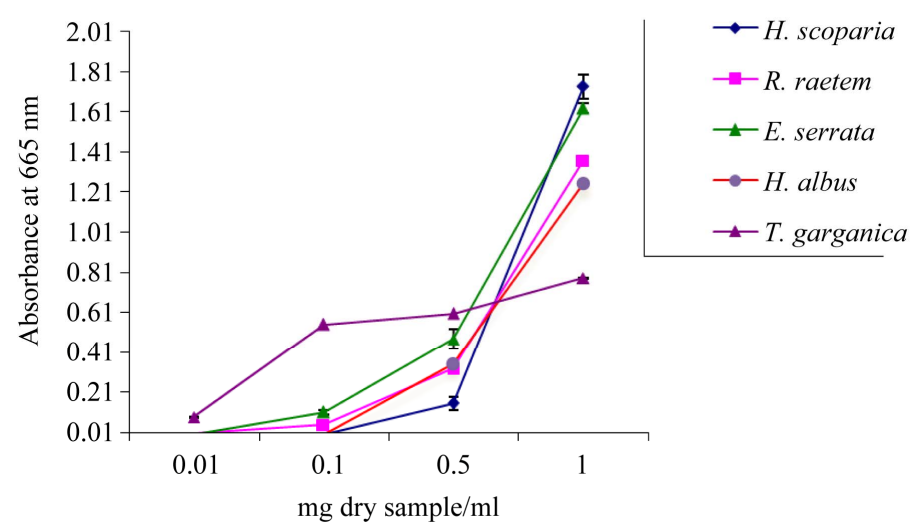

Figure 2. Reducing potential of methanolic plant extracts determined by FRAP activity assay. Data are mean \pm SD.

presented in the extracts. The intensity of the color reflects the absorption which is parallel to antioxidant activity [42]. Reducing potential was of concentrationdependent up to $1 \mathrm{mg} / \mathrm{ml}$ pattern and ranged from 0.78 in T. garganica to 1.73 in $H$. scoparia. The reducing power of $H$. scoparia extract was significantly higher as compared to $H$. albus, $T$. garganica and $R$. raetem extracts $(P$ $<0.05)$. The obtained results are comparable with those of the total phenolic and flavonoid contents (Table 2), indicating that these plants represent reliable source of antioxidants.

\subsubsection{Free Radicals Scavenging Activity}

2,2-diphenyl-1-picrylhydrazyl (DPPH) is a commercial oxidizing stable free radical, which is readily reduced by antioxidants. Increased reduction of DPPH is related to the high scavenging activity given by particular sample [43]. The $\mathrm{IC}_{50}$ was calculated, and expressed as the amount of antioxidant exists in the sample necessary to decrease the initial DPPH concentration by $50 \%$. The lower the $\mathrm{IC}_{50}$ value, the higher is the antioxidant activity.

Although all tested plant extracts were of observed antioxidant activity, the methanol extract of $H$. scoparia was able to reduce the DPPH concentration with an $\mathrm{IC}_{50}$ of $8 \pm 1.5 \mu \mathrm{g} / \mathrm{ml}$, which was stronger than that of control antioxidant, ascorbic acid, ( $\mathrm{IC}_{50}=10 \pm 1.6 \mu \mathrm{g} / \mathrm{ml}$ ) (Figure 3). The antioxidant activity of E. serrata and $R$. raetem extracts were less than $H$. scorpia extract, where $\mathrm{IC}_{50}$ of $E$. serrata and $R$. raetem extracts was five-folds higher than of that $H$. scorpia extract $(P<0.05)$. T. Garganica and $H$. albus extracts was showed the lowest antioxidant activity in comparison to tested extracts. The low antioxidant activity in DPPH assay is related to the amount of the total phenolic compounds of the plant [44]. Since, T. garganica has no considerable amounts of phenolic compound in the methanolic extract; yet it could be considered as moderate antioxidant which can be used for different purposes (Table 2) which is true also for $E$. serrata and $R$. raetem.

The correlation coefficient between antioxidant activity and total phenolic contents of the studied plants is $\mathrm{R}^{2}=0.77$ (Figure 4), whereas the correlation coefficient between the total flavonoids and antioxidant activity is equal to 0.98 (Figure 4). These results revealed that $77 \%$ of the antioxidant capacity is due to the contribution of the phenolic compounds.

The distinguishable relationship between the antioxidant activity and the total phenolics may be explained in various ways, in fact, the total phenolics content does not incorporate all the antioxidants. In addition, the synergism between the antioxidants in the mixture makes the antioxidant activity not only dependant on the concentration, but also on the structure and the interaction between the contained antioxidants. This can be explained because some plants like $H$. albus with respectable amount of phenolic compounds $(48 \mathrm{mg} / \mathrm{g})$ give low antioxidant activity compared with $T$. garganica extract (Table 2). The results confirm that there is a direct correlation between total phenolic content and antioxidant capacity of the medicinal plants [45].

\subsection{Antimicrobial and Antifungal Activities}

Many medicinal plants are considered to be potential antimicrobial crude drugs as well as a source of novel compounds such as flavonoids and alkaloids with antimicrobial activity $[46,47]$. This expectation that some naturally occurring plant ingredients can kill antibioticresistant strains of bacteria such as Bacillus cereus, Escherichia coli, Micrococcus luteus and Staphylococcus aureus has been confirmed [48].

The antimicrobial activities of medicinal plant extracts against microorganisms examined in the present study and their potency was qualitatively and quantitatively assessed by the presence or absence of inhibition zones, 


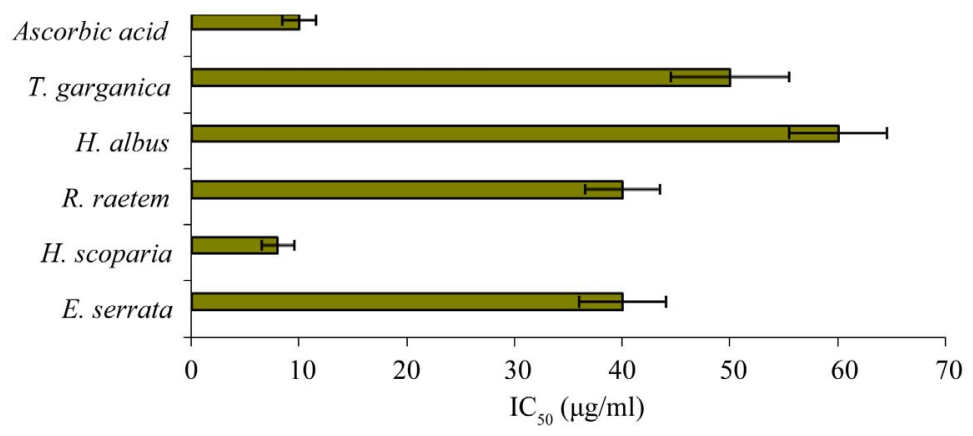

Figure 3. $\mathrm{IC}_{50}(\mu \mathrm{g} / \mathrm{ml})$ values of plant extracts for free radical scavenging activity by $\mathrm{DPPH}$ radical (A lower $\mathrm{IC}_{50}$ value indicates higher antioxidant activity; ascorbic acid was used as positive control).
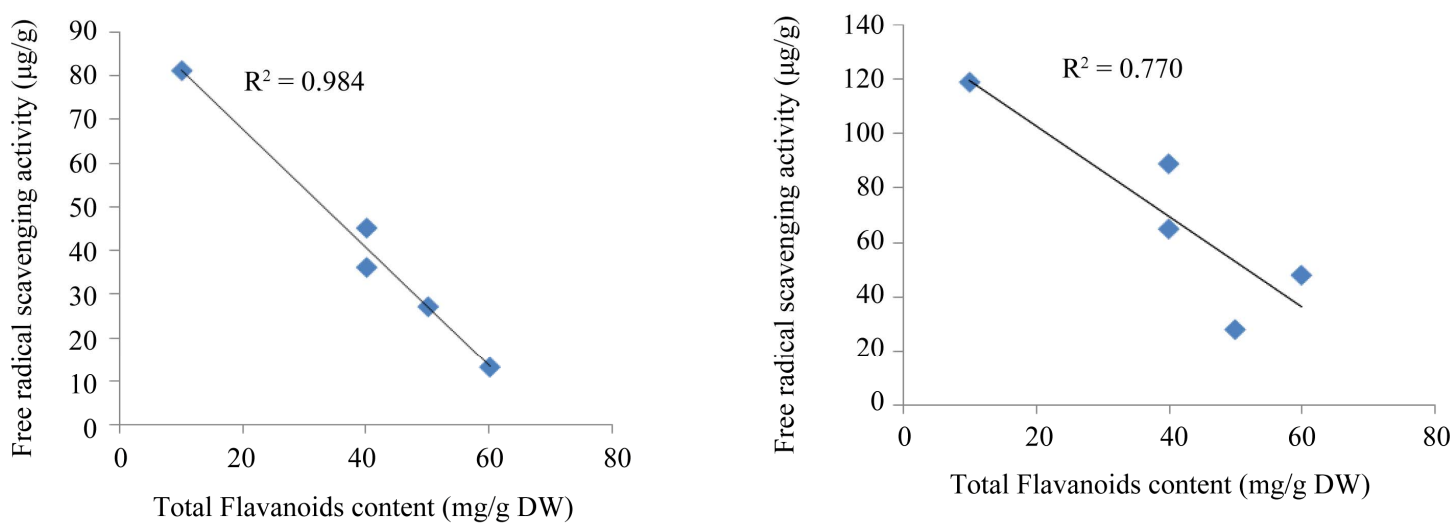

Figure 4. Linear correlation of free radical activity with respect to the total polyphenols and flavanoids content of the five tested Libyan plants.

zone diameter and MIC values. The results obtained from testing the extracts presented in Table 3 indicated moderate or high antimicrobial activity against some microorganisms. High antibacterial activity against most strains was attained by E. serrata and H. scoparia most probably due to their high content of phenolics and flavonoids, while the high activity of $H$. albus might be attributed to its high content of alkaloids

The antimicrobial effects of aqueous extracts (ambient or hot) of five medicinal plant species are shown in Table 3. It can be concluded that; the activity of cold water extracts was mostly of weak to very weak against both $\mathrm{G}$ $+\mathrm{ve}$ and $\mathrm{G}-\mathrm{ve}$ bacteria except $H$. albus and E. serrata. However, the antibacterial potential was increased notably using hot aqueous or methanol plant extracts.

The five plant extracts, in most cases, displayed remarkable antibacterial potential against all tested bacteria (Table 3). H. albus extract showed high antibacterial activity exceeds the reference antibiotics vancomycin and tetracycline (at $30 \mu \mathrm{g} / \mathrm{disc}$ ) since it gives DIZ range between $26-32 \mathrm{~mm}$ on $\mathrm{G}+\mathrm{ve}$ and $18-24 \mathrm{~cm}$ on G-ve bacteria. High antibacterial activity was also obtained from extracts of E. serrata and H. scoparia, which inhibited the growth of $E$. coli by $27 \mathrm{~mm}$ and $20 \mathrm{~mm}$, respec- tively. The biological activity of $H$. scoparia has been reported by other study [49].

Since the antibacterial activity tests demonstrated that, both crude methanolic and/or hot water extracts are of good bactericidal properties against susceptible bacteria (with variations between species), it was advisable to test them against antibiotic-resistant clinical isolates species, including the MRSA. It was found that extract of $\mathrm{H}$. scoparia, E. serrata and H. albus inhibited growth of some tested antibiotic-resistant microbes such as $P$. aeruginosa and MRSA. It was noteworthy that the MRSA growth was strongly inhibited by methanolic extract of $E$. serrata followed by $H$. scoparia and $H$. albus (Table 4).

Seeking quantitative expression of the antibacterial activity, the MICs of methanolic extracts of tested MPs were determined (Figure 5). The lowest MIC values were recorded with $H$. albus extract on $\mathrm{G}+\mathrm{ve}$ and $\mathrm{G}-\mathrm{ve}$ susceptible bacterial species with values between 3.13 $6.25 \mathrm{mg} / \mathrm{ml}$ (Figure 6). These values were 8 times higher on resistant strains of the same species (e.g. MRSA). The methanol extract of $E$. serrata showed high antimicrobial activity against Gram-positive bacteria than the other extracts with MICs of $3.13-6.25 \mathrm{mg} / \mathrm{ml}$ against $S$. aureus, E. coli, S. typhi, and MRSA. The R. raetem extract was 
Table 3. In vitro antibacterial activity of the aqueous and methanolic plant extracts against narrow spectrum of susceptible bacteria Well diameter: $8 \mathrm{~mm}$; W: water at $250^{\circ} \mathrm{C}$; $\mathrm{HW}$ : hot water $\left[70^{\circ} \mathrm{C}-80^{\circ} \mathrm{C}\right]$.

\begin{tabular}{|c|c|c|c|c|c|}
\hline \multirow{3}{*}{ Extract } & \multirow{3}{*}{ Solvent } & \multicolumn{4}{|c|}{ Inhibition Zone (mm) } \\
\hline & & \multicolumn{2}{|c|}{ Gram positive } & \multicolumn{2}{|c|}{ Gram negative } \\
\hline & & S. aur & B. sub & E. coli & S. typhi \\
\hline \multirow{3}{*}{ E. serrata } & $W$ & 17 & 8 & 20 & 14 \\
\hline & $H W$ & 15 & 12 & 12 & 18 \\
\hline & $\mathrm{MeOH}$ & 20 & 25 & 27 & 22 \\
\hline \multirow{3}{*}{ T. garganica } & $W$ & 8 & 10 & 10 & 10 \\
\hline & $H W$ & 12 & 10 & 11 & 14 \\
\hline & $\mathrm{MeOH}$ & 16 & 18 & 16 & 13 \\
\hline \multirow{3}{*}{ H. scoparia } & $W$ & 9 & 8 & 8 & 8 \\
\hline & $H W$ & 14 & 17 & 19 & 14 \\
\hline & $\mathrm{MeOH}$ & 20 & 14 & 20 & 18 \\
\hline \multirow{3}{*}{ R. raetem } & $W$ & 8 & 8 & 9 & 8 \\
\hline & $H W$ & 12 & 8 & 11 & 10 \\
\hline & $\mathrm{MeOH}$ & 19 & 16 & 14 & 14 \\
\hline \multirow{3}{*}{ H. albus } & $W$ & 17 & 19 & 15 & 10 \\
\hline & $H W$ & 17 & 17 & 20 & 18 \\
\hline & $\mathrm{MeOH}$ & 32 & 26 & 18 & 24 \\
\hline Vancomycin $(30 \mu \mathrm{g})$ & & 10 & 15 & 24 & 21 \\
\hline Tetracycline $(30 \mu \mathrm{g})$ & & 26 & 24 & 27 & 25 \\
\hline
\end{tabular}

S .aur: Staphylococcus aure; E. coli: Escherichia coli; B. sub: Bacillus subtilis; S. typhi: Salmonella typhi.

Table 4. In vitro antimicrobial activity of the methanolic plant extracts against resistant bacteria.

\begin{tabular}{cccccccc}
\hline Methanolic extract & E. agg & P. Syr & S. spp & S. mar & P. aer. & ESBL $^{+}$ & MRSA \\
\hline E. serrata & 8 & 8 & 8 & 8 & 19 & 13 & $\mathbf{3 5}$ \\
T. garganica & 8 & 8 & 8 & 8 & 10 & $\mathbf{2 5}$ & 15 \\
H. scoparia & $\mathbf{1 4}$ & $\mathbf{2 2}$ & $\mathbf{1 5}$ & $\mathbf{1 5}$ & $\mathbf{1 3}$ & $\mathbf{1 7}$ & $\mathbf{2 5}$ \\
R. raetem & 8 & 8 & 8 & 8 & 24 & 12 & 10 \\
H. albus & 8 & 9 & 8 & $\mathbf{1 8}$ & $\mathbf{2 1}$ & $\mathbf{3 0}$ & $\mathbf{2 4}$ \\
\hline
\end{tabular}

E. agg: Enterobacter agglomerans; P. syr: Pseudomonas syrenga; S. spp: Salmonella spp; S. mar: Serratia marcescens; P. aer: Pseudomonas aeruginosa; MRSA: Methicilline resistant staphylococcus aur; ESBL $^{+}$: Extended-spectrum $\beta$-Lactamases.
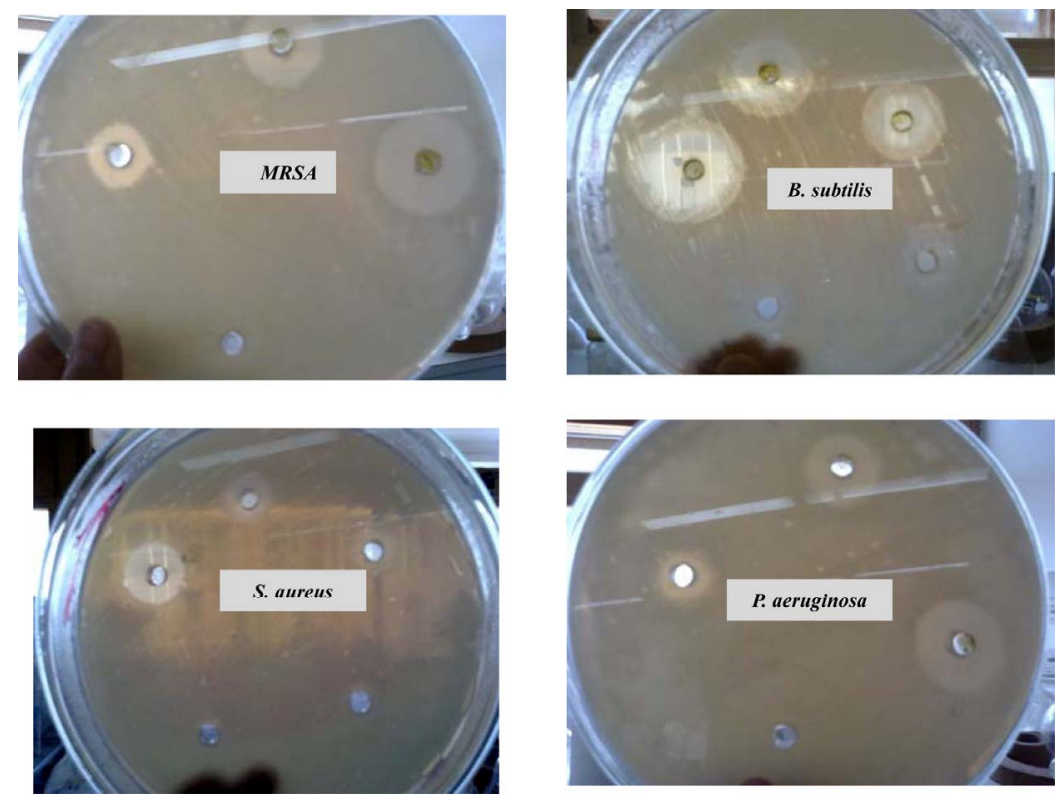

Figure 5. In vitro antibacterial activity (MIC) of methanolic extract of $H$. scoparia incubated with MRSA, B. subtilis, S. aureus and P. aeruginosa for $24 \mathrm{~h}$. 


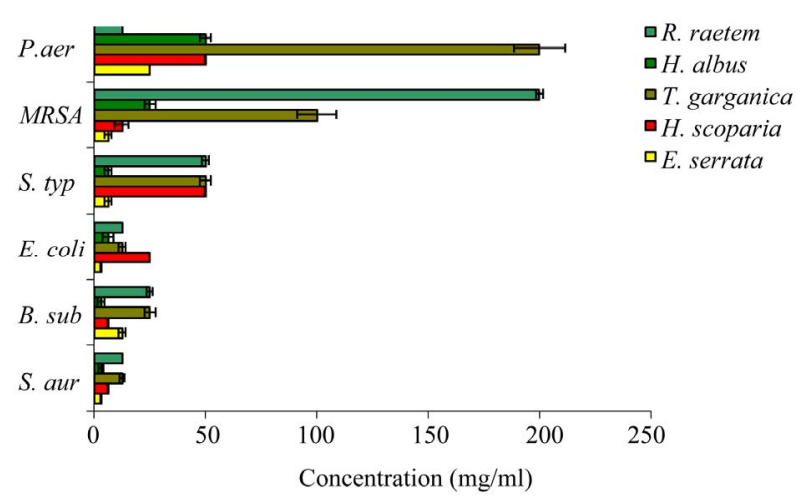

Figure 6. The in vitro antimicrobial activity of methanolic crude extracts of tested plants expressed as minimum inhibitory concentration (MIC) $(\mathrm{mg} / \mathrm{ml})$ against some bacteria. $S$. aur: Staphylococcus aureus; B. sub: Bacillus subtilis, E. coli: Escherichia coli; MRSA: Methicillin-resistant Stapylococcus aureus; P. aer: Pseudomonas aeruginosa (resistant); S. typhi: Salmonella typhi.

more effective as antimicrobial agent with relatively low MIC against $\mathrm{G}-$ ve such as $P$. aeruginosa in comparison with $\mathrm{G}+$ ve like $M R S A$. Methanol extracts of $R$. raetem flowers revealed high antimicrobial activity against Grampositive bacteria [47] which was in good agreement with our results. The high resistance of tested Gram-negative bacteria to external agents has been reported earlier, and it is mainly attributed to the presence of lipopoysaccharides in their outer cell membranes, which make them inherently resistant to antibiotics, detergent, and hydrophilic dyes [50]. The reason for higher sensitivity of the Gram-positive bacteria than Gramnegative bacteria could be attributed to the differences between their cell wall compositions. The Gram-positive bacteria contain an outer peptidoglycan layer instead of LPS, which is an ineffective permeability barrier [51,52]. Without outer membrane, the cell wall of Gram-positive ones can be permeated more easily and extracts can disturb the cytoplasmic membrane, the proton motive force (PMF), electron flow, active transport and coagulation of cell contents [1]. Therefore, the structural difference of bacterial cell wall plays an important role in their susceptibility. Collectively, $H$. albus followed by $H$. scoparia and $E$. serrata extracts were of higher potential as antimicrobials, (on basis of their MICs) regardless of the sensitivity of the test organisms (Susceptible or Resistant).

Although alkaloids are typical natural products of plants, it also produced by bacteria, fungi and animals produce alkaloids. It has been estimated that more than $20 \%$ of all plant species have alkaloids, especially members of the families Ranunculaceae, Berberidaceae, $\mathrm{Ca}$ ctaceae, Apocynaceae, Rutaceae, Solanaceae, Boraginaceae, and Leguminosae [53].

The antibacterial efficacy of the alkaloid extracts of the five investigated medicinal plants against susceptible and antibiotic-resistant bacteria of both species was investigated; the obtained results are shown in Table 5. The antimicrobial results showed that the $H$. albus alkaloid extract was effectively arrested growth of susceptible $\mathrm{G}+$ ve $(\mathrm{DIZ}=41-43 \mathrm{~mm}), \mathrm{G}-\mathrm{ve}(\mathrm{DIZ}=34-35$ $\mathrm{mm}$ ) including resistant bacteria, especially MRSA (DIZ $=32 \mathrm{~mm}$ ). These results showed high antimicrobial activity in comparison with the positive control. This can be partly attributed to the presence of higher alkaloidal content, as reported in other study [54].

Like the alkaloid extract of H. albus, E. serrata (DIZ = $21-41 \mathrm{~mm}$ ) and H. scoparia (DIZ = $22-37 \mathrm{~mm}$ ) alkaloid extracts showed similar results with remarkable effect against tested bacteria. Whereas, $R$. raetem $(\mathrm{DIZ}=$ $15-33 \mathrm{~mm}$ ) and $T$. garganica exhibited moderate effect $(\mathrm{DIZ}=19-24 \mathrm{~mm})$. E. serrata alkaloid extract was very effective on MRSA (DIZ 41 mm) compared with other plant species tested.

In terms of MIC values, the quantitative differences between the efficacies of alkaloid extracts of the five plants were determined and the results are illustrated in Figure 7. These results indicate that $H$. albus extract was of the lowest MIC value $(0.156 \mathrm{mg} / \mathrm{ml})$ on both $\mathrm{G}+\mathrm{ve}$ strains (B. subtilis and $S$. aureus). Alkaloid extract of $H$. scoparia showed the same effect at doubled MIC values $(0.313 \mathrm{mg} / \mathrm{ml})$ E. serrata alkaloid extract potentially affected $S$. aureus, E. coli, B. subtilis and S. typhi at MIC values of $0.156,0.313,0.625$ and $0.625 \mathrm{mg} / \mathrm{ml} \mathrm{respec-}$ tively (Figure 7). Although, it has been reported that other species of Rhamnacea family possess moderate antimicrobial and antiviral activities [55], the alkaloids extract of $H$. albus showed remarkable activity on $S$. aureus, E. coli and $S$. typhi with MIC values $0.156,0.313$ and $0.313 \mathrm{mg} / \mathrm{ml}$ respectively. It is most likely that the toxicity of plant members of this family is mostly related to the high concentration of the alkaloid in their extracts.

Antifungal activity of five botanical extracts was assayed against Rhizoctonia sp, Trichoderma sp, Sclerotium sp, Aspergillus and the obtained data are presented in Figure 8. The crude plant extracts of $R$. raetem and $H$. scoparia were exhibited significant reduction in the growth of four fungi which was in parallel with pervious study [48] (Figure 8(a)). It has been reported that raetem extract showed an antibacterial, antifungal and anticancer activity [56]. Alkaloids extract of $H$. scoparia and $H$. albus proved to be effective against tested fungi especially on Trichoderma spp, Sclerotium spp, Aspergillus niger.

H. scoparia demonstrated strong growth inhibition of the malaria parasite in earlier study [57]. In addition, methanolic $H$. scoparia extract demonstrated richness in alkaloids and showed significant molluscicidal activity [56], while $H$. albus extract exhibited antiviral activity [54]. The antifungal activity of alkaloids of $T$. garganica 
Table 5. In vitro antimicrobial activity of the alkaloid extract of the five tested Libyan medicinal plants against susceptible and resistant bacteria.

\begin{tabular}{|c|c|c|c|c|c|c|}
\hline \multirow{3}{*}{ Alkaloids extract } & \multicolumn{6}{|c|}{ Diameter of Inhibition Zone (mm)* } \\
\hline & \multicolumn{2}{|c|}{ Susceptible Gram +ve } & \multicolumn{2}{|c|}{ Susceptible Gram -ve } & \multicolumn{2}{|c|}{ Resistant Bacteria } \\
\hline & S. aur & B. sub & E. coli & S. typ & MRSA & P. aer \\
\hline H. scoparia & 31 & 33 & 29 & 30 & 37 & 22 \\
\hline R. raetem & 25 & 23 & 19 & 21 & 15 & 33 \\
\hline H. albus & 41 & 43 & 34 & 35 & 32 & 30 \\
\hline T. garganica & 24 & 22 & 20 & 19 & 20 & 24 \\
\hline E. serrata & 33 & 23 & 39 & 34 & 41 & 21 \\
\hline Vancomycin $(30 \mu g)$ & 10 & 15 & 24 & 21 & 8 & 8 \\
\hline Tetracycline (30 $\mu \mathrm{g})$ & 26 & 24 & 27 & 25 & 8 & 8 \\
\hline
\end{tabular}

Well diameter: 8 mm; S. aur: Staphylococcus aureus; B. sub: Bacillus subtilis; E. coli: Escherichia coli; S. typ: Salmonella typhi; MRSA: Methicillin-resistant; P. aer: Pseudomonas aeruginosa.

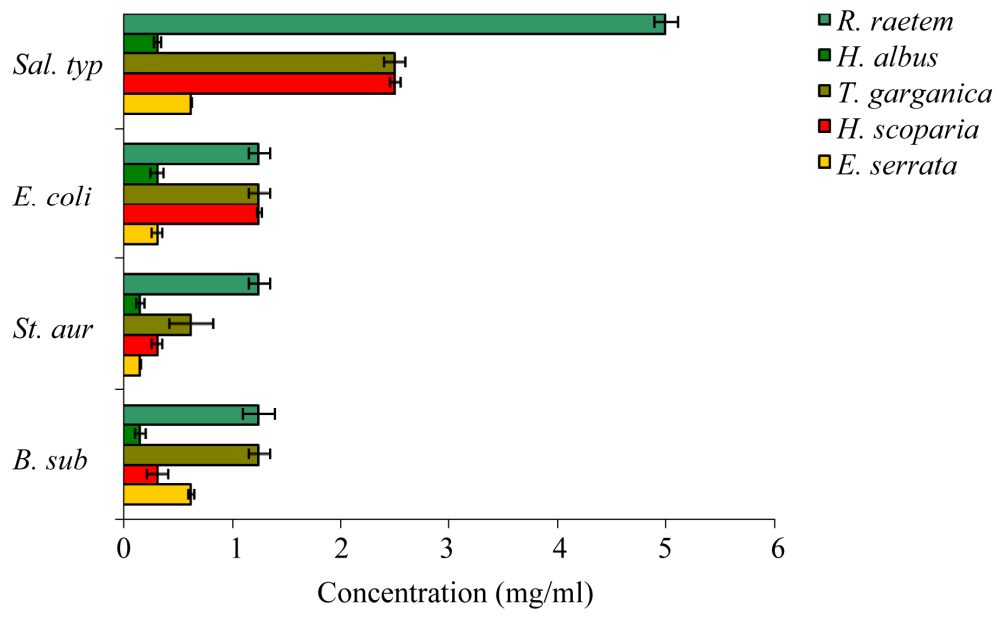

Figure 7. The in vitro MIC values $(\mathrm{mg} / \mathrm{ml})$ of alkaloid extracts of tested plants. S. aur: Staphylococcus aureus; B. sub: Bacillus subtilis; E. coli: Escherichia coil; S. typ: Salmonella typhi.

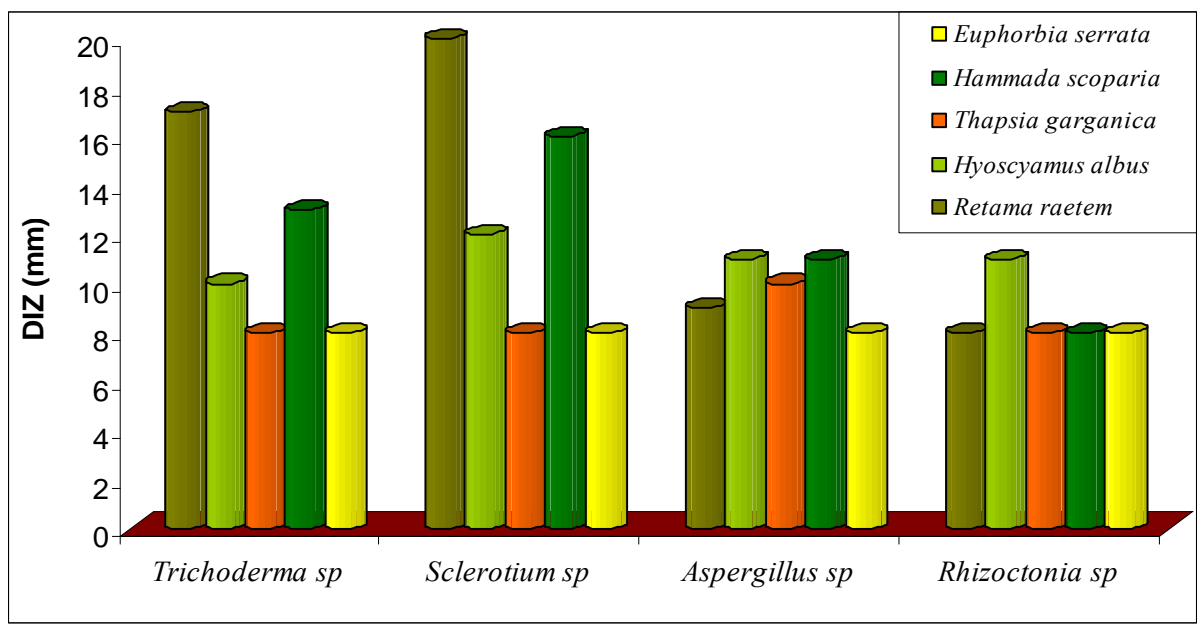

(a) 


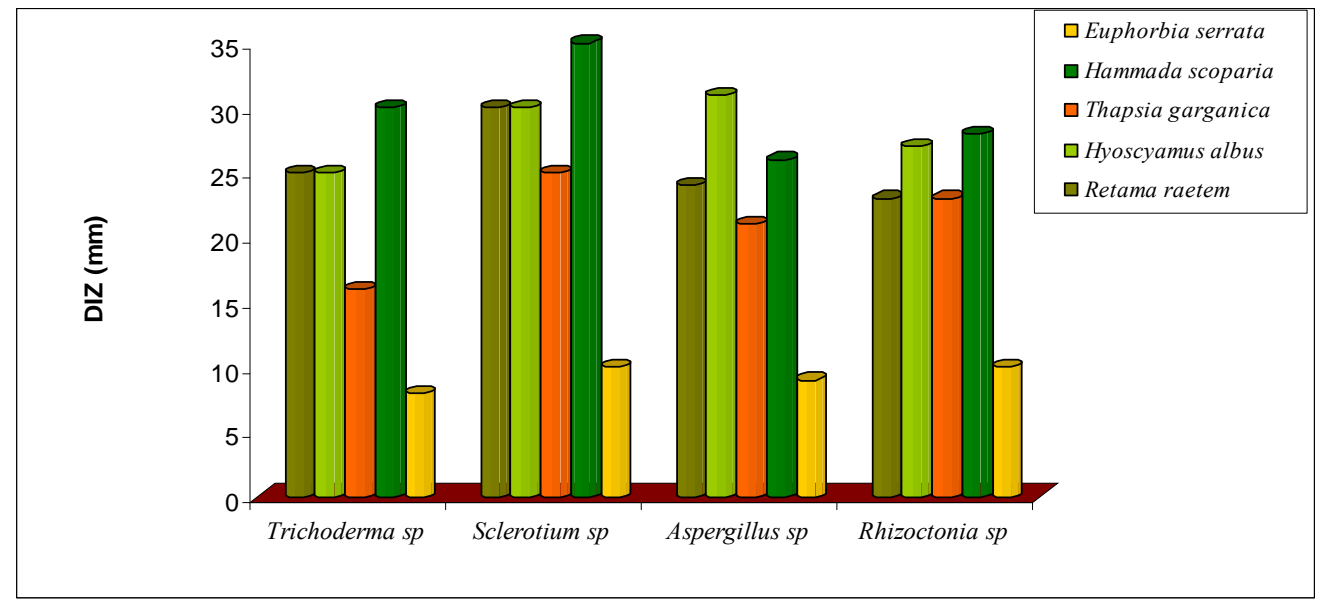

(b)

Figure 8. Antifungal activity of methanolic (a) and alkaloid (b) extracts of five selected medicinal plants.

was increased significantly in comparison with crude extract $(P<0.05)$. The alkaloids extract of $E$. serrata has lower antifungal activity compared with other alkaloid extracts which might be due to its comparatively low alkaloid content (Figure 8(b)), this study suggests that methanolic extracts of the screened plants would be helpful in treating diseases in plants caused by Rizochtonia solani, Trichoderma spp, Sclerotium spp and Aspergillus niger.

\section{CONCLUSION}

Antioxidative and antimicrobial properties of the medicinal plants are proven to be of great interest in both health and industry due to their possible uses as natural food additives to replace synthetic ones. In this respect, the present study was designed to evaluate the in vitro antioxidant properties and antimicrobial activity of five Libyan medicinal plant extracts against various microorganisms. The results presented here can be considered as the first information on the antioxidant and antimicrobial properties of those plants that have traditional uses in Libya. H. scoparia and $R$. raetem may be useful as excellent antioxidant, antibacterial and antifungal agents while $T$. garganic can be considered as a good source of antioxidant and antimicrobial agents. Additional studies are required on the mode of action of the active ingredients on pathogenic microorganisms. Despite the significant effect of E. serrata extract against both bacteria and fungi, it belongs to a family that is known to be toxic. Therefore, consumers of any of the investigated plants should also be familiar with science-based information on dosage, contraindications, and efficacy.

\section{REFERENCES}

[1] Burt, S. (2004) Essential oils: Their antibacterial proper- ties and potential applications in foods. International Journal of Food Microbiology, 94, 223-253. doi:10.1016/j.ijfoodmicro.2004.03.022

[2] Isman, B.M. (2000) Plant essential oils for pest and disease management. Crop Protection journal, 19, 603-608.

[3] Liu, Y.J. and Zhang, K.Q. (2004) Antimicrobial activity of selected Cyathus species. Mycopathologia, 157, 185189. doi:10.1023/B:MYCO.0000020598.91469.d1

[4] Mares, D., Romagnoli. C., Tosi, B., Andreotti. E., Chillemi. G. and Poli, F. (2005) Chicory extracts from Cichorium intybus $L$. as potential antifungals. Mycopathologia, 160, 85-92. doi:10.1007/s11046-004-6635-2

[5] Soylu, E.M., Soylu, S. and Kurt, S. (2006) Antimicrobial activities of the essential oils of various plants against tomato late blight disease agent Phytophthora infestans. Mycopathologia, 161, 119-128. doi:10.1007/s11046-005-0206-Z

[6] Yazaki, K., Sugiyama, A., Morita, M. and Shitan, N. (2008) Secondary transport as a efficient membrane transport mechanism for plant secondary metabolites. Phytochemistry Review, 7, 513-524. doi:10.1007/s11101-007-9079-8

[7] Akhtar, Y., Rankin, K. and Isman, M. (2008) Decreased Response to Feeding Deterrents Following Prolonged Exposure in the Larvae of a Generalist Herbivore, Trichoplusia ni (Lepidoptera: Noctuidae). Phytochemistry Review, 7, 77-88. doi:10.1007/s11101-006-9048-7

[8] Naili, M., Alghazeer, R., Saleh., N. and Al-Najjar, A. (2010) Evaluation of antibacterial and antioxidant activities of Artemisia campestris (Astraceae) and Ziziphus lotus (Rhamnacea). Arabian Journal of Chemistry, 3, 73134. doi:10.1016/j.arabjc.2010.02.002

[9] Li, J.W. and Vederas, J.C. (2009) Drug discovery and natural products: End of an era or an endless frontier? Science, 325, 161-165. doi:10.1126/science.1168243

[10] Hartmann, T. (2007) From waste products to ecochemicals: 50 years research on plant secondary metabolism. Phytochemistry, 68, 2831-2846. doi:10.1016/j.phytochem.2007.09.017 
[11] Jenke-Kodama, H., Müller, R. and Dittmann, E. (2008) Evolutionary mechanisms underlying secondary metabolite diversity. Progress in Drug Research, 65, 121-140.

[12] Suhaj, M. (2006) Spice antioxidants isolation and their antiradical activity: A review. Journal of Food Composition and Analysis, 19, 531-537. doi:10.1016/j.jfca.2004.11.005

[13] Akinmoladun, A., Ibukun, E., Afor, E., Obuotor, E. and Farombi, E. (2007) Phytochemical constituent and antioxidant activity of extract from the leaves of Ocimum gratissimum. Scientific Research and Essays, 2, 163-166.

[14] Alghazeer, R., Gao, H. and Howell, N.K. (2008) Cytotoxicity of oxidised lipids in cultured colonal human intestinal cancer cells (caco-2 cells). Toxicology Letters, 180, 202-211. doi:10.1016/j.toxlet.2008.06.859

[15] Nychas, G.J.E. (1995) Natural antimicrobial from plants. In: Gould, G.W., Ed., New Method of Food Preservation, Chapman and Hall, Glasgow, 58-89. doi:10.1007/978-1-4615-2105-1 4

[16] Gülçin, I., Oktay, M., Küfrevioğlu, O.I. and Aslan, A. (2002) Determination of antioxidant activity of lichens Cetraria islandica (L) Ach. Journal of Ethnopharmacology, 79, 325-329. doi:10.1016/S0378-8741(01)00396-8

[17] Jayaprakasha, G.K., Jaganmohan Rao, L. and Sakariah, K.K. (2006) Antioxidant activities of curcumin, demethoxycurcumin and bisdemethoxycurcumin. Food Chemistry, 98, 720-724. doi:10.1016/j.foodchem.2005.06.037

[18] Lindsay, D.G. and Astley, S.B. (2002) European research on the functional effects of dietary antioxidants. Molecular Aspects of Medicine, 23, 1-38. doi:10.1016/S0098-2997(02)00005-5

[19] Fadeyi, M.G., Adeoye, A.E. and Olowokodejo, J.D. (1989) Epidermal and phytochemical studies with genus of Boerhavia (Nyetanginaceae). International Journal of Crude Drug Research, 29, 178-184.

[20] Odebiyi, A. and Sofowora, A.E. (1990) Phytochemical screening of nigerian medicinal plants. Part III. Lloydia, 41, 234-246.

[21] Harborne, J.B. (1992) Phytochemical methods. Chapman and Hall Publications, London, 7-8.

[22] Abulude, F.O., Onibon, V.O. and Oluwatoba, F. (2004) Nutrition and nutritional composition of some tree barks. Nigerian Journal of Basic and Applied Sciences, 13, 4349.

[23] Abulude, F.O. (2007) Phytochemical screening and mineral contents of leaves of some Nigerian woody plants. Research Journal of Phytochemistry, 1, 33-39. doi:10.3923/rjphyto.2007.33.39

[24] Hadi, S. and Bremner, B. (2001) Initial studies on alkaloids from Lombok medicinal plants. Molecules, 6, 117129. doi: $10.3390 / 60100117$

[25] Marinova, D., Ribarova, F. and Atanassova, M. (2005) Total phenolics and total flavonoids in Bulgarian fruits and vegetables. Journal of Chemical Technology and Biotechnology, 40, 255-260.

[26] Oyaizu, M. (1986) Studies on product of browning reaction prepared from glucose amine. Japanese Journal of
Nutrition, 44, 307-315

doi:10.5264/eiyogakuzashi.44.307

[27] Singleton, V.L., Orthofer, R. and Lamuela-Raventos, R.M. (1999) Analysis of total phenols and oxidization substrates and antioxidants by means of Folin-Ciocalteu reagent. Methods in Enzymology, 299, 152-177. doi:10.1016/S0076-6879(99)99017-1

[28] Wong, C., Li, H. and Cheng, F. (2006) A systematic survey of antioxidant activity of 30 Chinese medicinal plants using the ferric reducing antioxidant power assay. Food Chemistry, 97, 705-711. doi:10.1016/j.foodchem.2005.05.049

[29] Daud, A., Gallo, A. and Sanchez, A. (2005) Antimicrobial properties of Phrygilanthus acutifolius. Journal of Ethnopharmacology, 99, 193-197. doi:10.1016/j.jep.2005.01.043

[30] CLSI (2008) Reference method for broth dilution antifungal susceptibility testing of filamentous fungi. Approved Standard M38-A2, Clinical and Laboratory Standards Institute, Wayne.

[31] Romero, C., Medina, E., Vargas, J., Brenes, M. and De, Castro (2007) Activity of olive polyphenols against Helicobactor pylori. Journal of Agricultural and Food Chemistry, 55, 680-686. doi:10.1021/jf0630217

[32] Irith, W., Kai, H. and Robert, E.W.H. (2008) Agar and broth dilution methods to determine the minimal inhibitory concentration (MIC) of antimicrobial substances. Nature Protocols, 3, 163-175. doi:10.1038/nprot.2007.521

[33] Ayoola, G.A., Sofidiya, T., Odukoya, O. and Coker, A.B. (2006) Phytochemical screening and free radical scavenging activity of some Nigerian medicinal plants. International Journal of Pharmacy and Pharmaceutical Practice, 8, 133-136.

[34] Zheng, X., Liu, B., Li, L. and Zhu, Z. (2011) Microwave-assisted extraction and antioxidant activity of total phenolic compounds from pomegranate peel. Journal of Medicinal Plants Research, 15, 1004-1011.

[35] Esmaeili, M.A. and Sonboli, A. (2010) Antioxidant, free radical scavenging activities of Salvia brachyantha and its protective effect against oxidative cardiac cell injury. Food and Chemical Toxicology, 48, 846-853. doi:10.1016/j.fct.2009.12.020

[36] Leake, D. (2001) Flavonoids and the oxidation of lowdensity lipoprotein. Nutrition, 17, 59-63. doi:10.1016/S0899-9007(00)00485-8

[37] Aviram, M. and Fuhrman, B. (1998) Polyphenolic flavonoids inhibit macrophage-mediated oxidation of LDL and attenuate atherogenesis. Atherosclerosis, 137, S45S50. doi:10.1016/S0021-9150(97)00306-7

[38] Reddy, L., Odhav, B. and Bhoola, K.D. (2003) Natural products for cancer prevention: A global perspective. Pharmacology \& Therapeutics, 99, 1-13. doi:10.1016/S0163-7258(03)00042-1

[39] Kandaswami, C., Lee, L.T., Lee, P.P., Hwang, J.J., Ke, F.C., Huang, Y.T. and Lee, M.T. (2005). The antitumor activities of flavonoids. In Vivo, 19, 895-909. 
[40] Kassem, M., Mosharrafa, S.A., Saleh, N.A. and AbdelWahab, S.M. (2000) Two new flavonoids from Retama raetam. Fitoterapia, 71, 649-654. doi:10.1016/S0367-326X(00)00224-0

[41] Djeridane, A., Yousfi, M., Nadjemi, B., Boutassouna, D., Stocker, P. and Vidal, N. (2006) Antioxidant activity of some Algerian medicinal plants extracts containing phenolic compounds. Food Chemistry, 97, 654-660. doi:10.1016/j.foodchem.2005.04.028

[42] Zou Y., Lu, Y. and Wei, D. (2004) Antioxidant activity of a flavonoid-rich extract of Hypericum perforatum L. in vitro. Journal of Agricultural and Food Chemistry, 52, 5032-5039. doi:10.1021/jf049571r

[43] Molyneux, P. (2004) The use of the stable free radical diphenylpicrylhydrazyl (DPPH) for estimating antioxidant activity. Songklanakarin Journal of Science and Technology, 26, 211-219.

[44] Katalinic, V., Milos, M., Kulisic, T. and Jukic, M. (2006) Screening of 70 medicinal plant extracts for antioxidant capacity and total phenols. Food Chemistry, 94, 550-557. doi:10.1016/j.foodchem.2004.12.004

[45] Brighente, I.M.C., Dias, M., Verdi, L.G. and Pizzolatti, M.G. (2007) Antioxidant activity and total phenolic content of some Brazilian species. Pharmaceutical Biology, 45, 156-161. doi:10.1080/13880200601113131

[46] Rastogi, R.P. and Mehrotra, B.N. (2002) Glossary of Indian medicinal plants. National Institute of Science Communication, New Delhi.

[47] Parekh, J., Jadeja, D. and Chanda, S. (2005) Efficacy of Aqueous and Methanol extracts of some medicinal plants for potential antibacterial activity. Turkish Journal of Biology, 29, 203-210.

[48] Edziri, H., Mastouri, M., Chéraif, I. and Aouini, M. (2010) Chemical composition and antibacterial, antifungal and antioxidant activities of the flower oil of Retama raetam (Forssk.) Webb from Tunisia. Natural Product Research, 24, 789-796. doi:10.1080/14786410802529190

[49] Abutbul, S., Golan-Goldhirsh, A. Barazani, O. Ofir, R. and Zilberg, D. (2005). Sscreening of the desert plants for use against bacterial pathogens in fish. The Israeli Jour- nal of Aquaculture-Bamidgeh, 57, 71-80.

[50] Nikaido, H. (2003) Molecular basis of bacterial outer membrane permeability revisited. Microbiology and Molecular Biology Reviews, 67, 593-656. doi:10.1128/MMBR.67.4.593-656.2003

[51] Matias, V.R. and Beveridge, T.J. (2006) Native cell wall organization shown by cryoelectron microscopy confirms the existence of a periplasmic space in Staphylococcus aureus. Journal of Bacteriology, 188, 1011-1021. doi:10.1128/JB.188.3.1011-1021.2006

[52] Hayder, N., Bouhlel, I., Skandrani, I., Kadri, M., Steiman, R., Guiraud, P., Mariotte, A.M., Ghedira, K., DijouxFranca, M.G. and Chekir-Ghedira, L. (2008) In vitro antioxidant and antigenotoxic potentials of myricetin-3o-galactoside and myricetin-3-o-rhamnoside from Myrtus communis: modulation of expression of genes involved in cell defense system using cDNA microarray. Toxicology in Vitro, 22, 567-581. doi:10.1016/j.tiv.2007.11.015

[53] Rahman, A. (2000) Studies in natural products chemistry. Bioactive Natural Products (Part B), 21, 3-122.

[54] Dawidar, A.M., Abdel-Mogib, M., El-Ghorab, A.H. and Hussien, Kh. (2009) Chemical composition and effect of photooxygenation on biological activities of Egyptian commercial spearmint and dill essential oils. Mansoura Journal of Chemistry, 36, 49-60.

[55] Budzanivska, I.G. and Demyanenko, F. (2002) Inhibition of Solanaceae plants by combined effect of increased concentrations of heavy metals and viral infection. Plant Protection Science, 38, 452-454.

[56] Merghoub, N., Benbacer, L., Amzazi, S., Morjani, H. and El Mzibri, M. (2009) Cytotoxic effect of some Moroccan medicinal plant extracts on human cervical cell lines. Journal of Medicinal Plants Research, 3, 1045-1050.

[57] Mezghani-Jarraya, R., Hammami, H., Ayadi, A. and Damak, M. (2009) Molluscicidal activity of Hammada scoparia (Pomel) Iljin leaf extracts and the principal alkaloids isolated from them against Galba truncatula. Memórias do Instituto Oswaldo Cruz, 104, 1035-1038. doi:10.1590/S0074-02762009000700017 